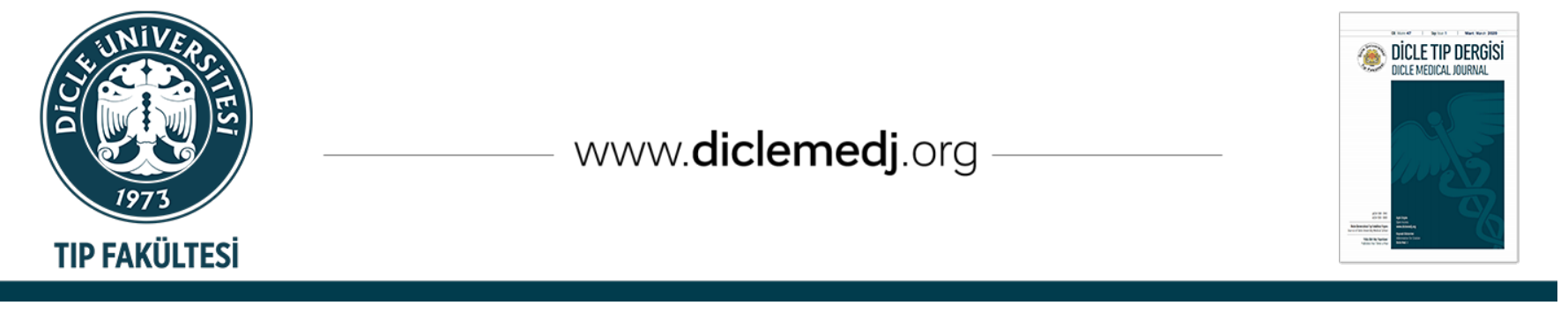

Original Article / Özgün Araştırma

\title{
The Most Important Factors in Prognosis Of Obstetric Patients with Disseminated Intravascular Coagulation: A Tertiary Center Study
}

\author{
Abdulkadir Turgut ${ }^{i}{ }_{1}$, Nurullah Peker ${ }^{\left(D_{2}\right.}$, Elif Ağaçayak ${ }^{i}{ }_{2}$, Gamze Akın Evsen ${ }^{D_{2}}$, Edip Aydın ${ }^{\left(D_{3}\right.}$,

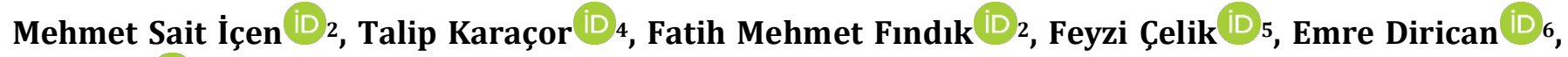 \\ Talip Gül iD2
}

1 Department of Obstetrics and Gynecology, Medeniyet University School of Medicine, İstanbul, Turkey

2 Department of Obstetrics and Gynecology, Dicle University School of Medicine, Diyarbakır, Turkey

3 Department of Obstetrics and Gynecology, Health Sciences University Gazi Yasargil Training and Research Hospital, Diyarbakir, Turkey

4 Department of Obstetrics and Gynecology, Adlyaman University School of Medicine, Adlyaman, Turkey

5 Department of Anesthesia, Dicle University School of Medicine, Diyarbakır, Turkey

6 Department of Biostatistics, Dicle University School of Medicine, Diyarbakır, Turkey

Received: 05.06.2020; Revised: 09.07.2020; Accepted: 22.07.2020

\begin{abstract}
Objective: The aim of this study was to investigate the underlying causes of obstetrical disseminated intravascular coagulation (DIC) and to evaluate the laboratory and clinical signs affecting DIC-related morbidity and mortality in women diagnosed with obstetrical DIC in a tertiary referral hospital.

Method: The retrospective study included women with DIC who either had a delivery at Dicle University Medical School Gynecology and Obstetrics Department or were referred to this department prior to delivery between May 2006 and May 2016. DIC scoring was performed using the DIC scoring system developed by the International Society of Thrombosis and Hemostasis (ISTH) in 2001.

Results: A total of 82 women with obstetrical DIC were included in the study. The incidence of obstetrical DIC in our department was $0.41 \%$. Overall mortality rate was $24 \%$ and mortality occurred in $8 \%$ of the patients with a DIC score of $\leq 5$ and in $12 \%$ of the patients with a score of $>5(\mathrm{p}=0.043)$. Multiple logistic regression analysis indicated that increased INR (International Normalized Ratio) and ALT (Alanin Aminotransferaz) levels led to a significant increase in DIC-related mortality [OR: 1.803 (CI: 1.027-3.167), 0R: 1.003 (CI: 1.001-1.005), respectively].
\end{abstract}

Conclusions: Obstetrical DIC may result in high mortality and morbidity. DIC scoring can be useful for predicting the prognosis and DIC-related mortality. INR and ALT is the most important laboratory parameter in DIC and also can affect mortality.

Keywords: disseminated intravascular coagulation (DIC), mortality, obstetrics, prognosis.

DOI: 10.5798/dicletip.799622

Correspondence / Yazışma Adresi: Elif Agacayak, Dicle University School of Medicine, Department of Gynecology and Obstetrics, 21280, Diyarbakir, Turkeye-mail: drelifagacayak@gmail.com 


\section{Obstetrik Dissemine İntravasküler Kuagülasyonlu Hastaların Prognozunda En Önemli Faktörler: Tersiyer Bir Merkez Çalışması}

Öz

Amaç: Bu çalıșmanın amacl, obstetrik nedenli dissemine intravasküler kuagülasyonun (DİK) altta yatan nedenlerini araștırmak ve üçüncü basamak refere bir hastanede obstetrik DİK tanısı alan kadınlarda DİK ile ilişkili morbidite ve mortaliteyi etkileyen laboratuvar ve klinik bulguları değerlendirmektir.

Yöntemler: Bu retrospektif çalışmada Dicle Üniversitesi Tıp Fakültesi Kadın Hastalıkları ve Doğum Anabilim Dalı'nda Mayıs 2006 ile Mayıs 2016 arasında doğum yapmış olan veya doğumdan önce bu bölüme sevk edilen DİK' li hastaları içermekteydi. DİK puanlaması, 2001 yılında Uluslararası Tromboz ve Hemostaz Derneği tarafından geliştirilen DİK puanlama sistemi kullanılarak yapıldı.

Bulgular: Toplamda 82 obstetrik DİK hastası çalıșmaya dahil edildi. Kliniğimizde obstetrik DİK insidansı \%0,41 idi. Genel mortalite oranı \%24, DIC skoru $\leq 5$ olan hastaların \%8'inde ve skoru> 5 olan hastaların \%12'sinde mortalite görülmüştür (p = 0.043). Çoklu lojistik regresyon analizi, artmış INR ve ALT seviyelerinin DİK ile ilişkili mortalitede önemli bir artışa yol açtığını göstermiştir [OR: 1.803 (CI: 1.027-3.167), OR: 1.003 (CI: 1.001- 1.005).

Sonuç: Obstetrik DİK yüksek mortalite ve morbidite ile sonuçlanabilir. DİK skorlaması, prognoz ve DIC ile ilişkili mortaliteyi tahmin etmek için yararlı olabilir. INR ve ALT, DİK' deki en önemli laboratuvar parametresidir ve mortaliteyi de etkileyebilmektedir.

Anahtar kelimeler: Dissemine intravasküler kuagülasyon, mortalite, obstetrik, prognoz.

\section{INTRODUCTION}

Disseminated intravascular coagulation (DIC) is a systemic condition characterized by thrombosis and hemorrhage and is also known as the pathological activation of the physiological hemostatic process. As a result of massive activation of the coagulation cascade, DIC results in diffuse thrombi, thereby leading to excess thrombin and reduction of coagulation factors and platelets ${ }^{1}$. This in turn may result in hemorrhage, thrombosis, and/or multiple organ failure. It is commonly known that DIC is not a stand-alone disease and always occurs secondary to an underlying condition. Moreover, DIC may occur during the course of numerous diseases and also has unique features. Most of the clinical signs arising from DIC result from the excess circulating thrombin that often occurs secondary to an underlying condition such as sepsis, obstetric/gynecological disorders, trauma, malignancy, solid tumors, vascular anomalies, toxic and immunological reactions, and $\mathrm{ABO}$ incompatibility. Of these, common obstetric conditions include postpartum bleeding, hypertensive disorders during pregnancy, HELLP syndrome, acute fatty liver, ablatio placentae, amniotic fluid embolism, intrauterine fetal death, molar pregnancy, postpartum endometritis, chorioamnionitis, and septic abortion ${ }^{2}$.

DIC is a confusing syndrome and there is no consensus on the standard treatment method for DIC since it can result from a wide variety of diseases, it can present with different clinical and laboratory signs, and its clinical course varies greatly among patients. Therefore, there are significant differences among the modalities used for the management, diagnosis, and treatment of $\mathrm{DIC}^{3}$.

Obstetrical DIC has been shown to have a prevalence of 12.5 in 10000 births $^{4}$. Despite this low prevalence, women with DIC have high rates of specific complications of pregnancy. The most common cause of DIC in pregnant women is peripartum hemorrhage, which has a prevalence of $1-5 \%$ among all DIC patients in developed countries. However, this rate is considered to be higher in developing countries ${ }^{5,6}$.

The aim of this study was to investigate the underlying causes of obstetrical DIC and to 
evaluate the laboratory and clinical signs affecting DIC-related morbidity and mortality.

\section{METHODS}

The retrospective study included women with DIC who either had a delivery at Dicle University Medical School Gynecology and Obstetrics Department or were referred to this department prior to delivery between May 2006 and May 2016. The study was approved by the local Ethics Committee (no:210).

DIC was scored by using the DIC scoring system developed by the International Society of Thrombosis and Hemostasis (ISTH) in 2001. Table 1 presents the criteria used for scoring7.

Table I: Criteria for the diagnosis of overt DIC based on the ISTH scoring system (7).

1. Risk assessment: Does the patient have an underlying disorder known to be associated with overt DIC?

If yes: proceed; if no: do not use this algorithm:

2. Order global coagulation tests (platelet count, prothrombin time (PT), fibrinogen, soluble fibrin monomers or fibrin degradation products).

3. Score global coagulation test results

platelet count $(>100=0 ;<100=1 ;<50=2)$

elevated fibrin-related marker (e.g. soluble fibrin monomers/fibrin degradation products)

(no increase: 0; moderate increase: 2; strong increase: 3) prolonged prothrombin time

$(<3 \mathrm{~s}=0 ;>3 \mathrm{~s}$ but $<6 \mathrm{~s}=1 ;>6 \mathrm{~s}=2)$

fibrinogen level $(>1.0 \mathrm{~g} / \mathrm{l}=0 ;<1.0 \mathrm{~g} / \mathrm{l}=1)$.

4. Calculate score.

5. If > 5: compatible with overt DIC; repeat scoring daily.

If < 5: suggestive (not affirmative) for non-overt DIC; repeat in the next 1-2 days.

The patients were divided into 4 groups depending on the underlying cause of DIC: (I) hypertensive pregnancies, (II) postpartum hemorrhage, (III) ablatio placentae, and (IV) other causes (amniotic fluid embolism, intrauterine fetal death, sepsis). Exclusion criteria were as follows: gynecological diseases (malignancy, thrombophlebitis, and infection), vasculitis associated with platelet consumption, thrombotic thrombocytopenic purpura (TTP), hemolytic uremic syndrome (HUS), antineoplastic therapy, hematologic malignancies associated with DIC, blood transfusion reaction, crush injury, hemorrhagic pancreatitis, other malignancies, and chronic inflammatory diseases.

Age, gender, mode of delivery, requirement of postpartum blood transfusion (types and volumes of the blood products transfused), hospital stay, morbidity, and previous surgeries were recorded for each patient. The types and volumes of the blood products transfused, surgical procedures, requirement of secondary surgery, and the causes of post-discharge morbidities and mortality were also noted for each patient. Complete blood count (CBC) included hemoglobin (HGB), hematocrit (HCT), platelet (PLT), white blood count (WBC), alanine aminotransferase (ALT), aspartate aminotransferase (AST), lactate dehydrogenase (LDH), urea, creatine, total bilirubin, international normalized ratio (INR), activated partial thromboplastin time (A-PTT), partial thromboplastin time (PTT), fibrinogen, and Ddimer level.

\section{Statistical Analysis}

Data were analyzed using SPSS 15 for Windows (SPSS Inc., Chicago, IL, USA). Normal distribution was tested by using the ShapiroWilk test. Parametric data with normal distribution were analyzed by using the test and nonparametric data were analyzed by using the Mann-Whitney U test. Categorical variables were analyzed using chi-square test. Descriptive statistics were used for evaluating the demographic characteristics and the laboratory signs. A $p$ value of $<0.05$ was considered significant.

\section{RESULTS}

A total of 21058 deliveries were performed in our department between May 2006 and May 
2016. Within this period, 82 women were diagnosed as having DIC based on the physical examination findings and laboratory signs, which indicates an incidence of $0.41 \%$ for obstetrical DIC for the patients evaluated within this period.

Of the 82 women, 28 (34.14\%) had a normal delivery and 54 (65.86\%) had a cesarean delivery. Table 2 presents patient characteristics, length of stay at the intensive care unit (ICU), and laboratory signs. Table 3 presents the mortality rates for all groups. Hypertension and ablation placenta were seen together in one patient. Figure 1 presents the volumes of the transfusion of blood components with regards to mortality.

Table II: Patient characteristics and laboratory parameters.

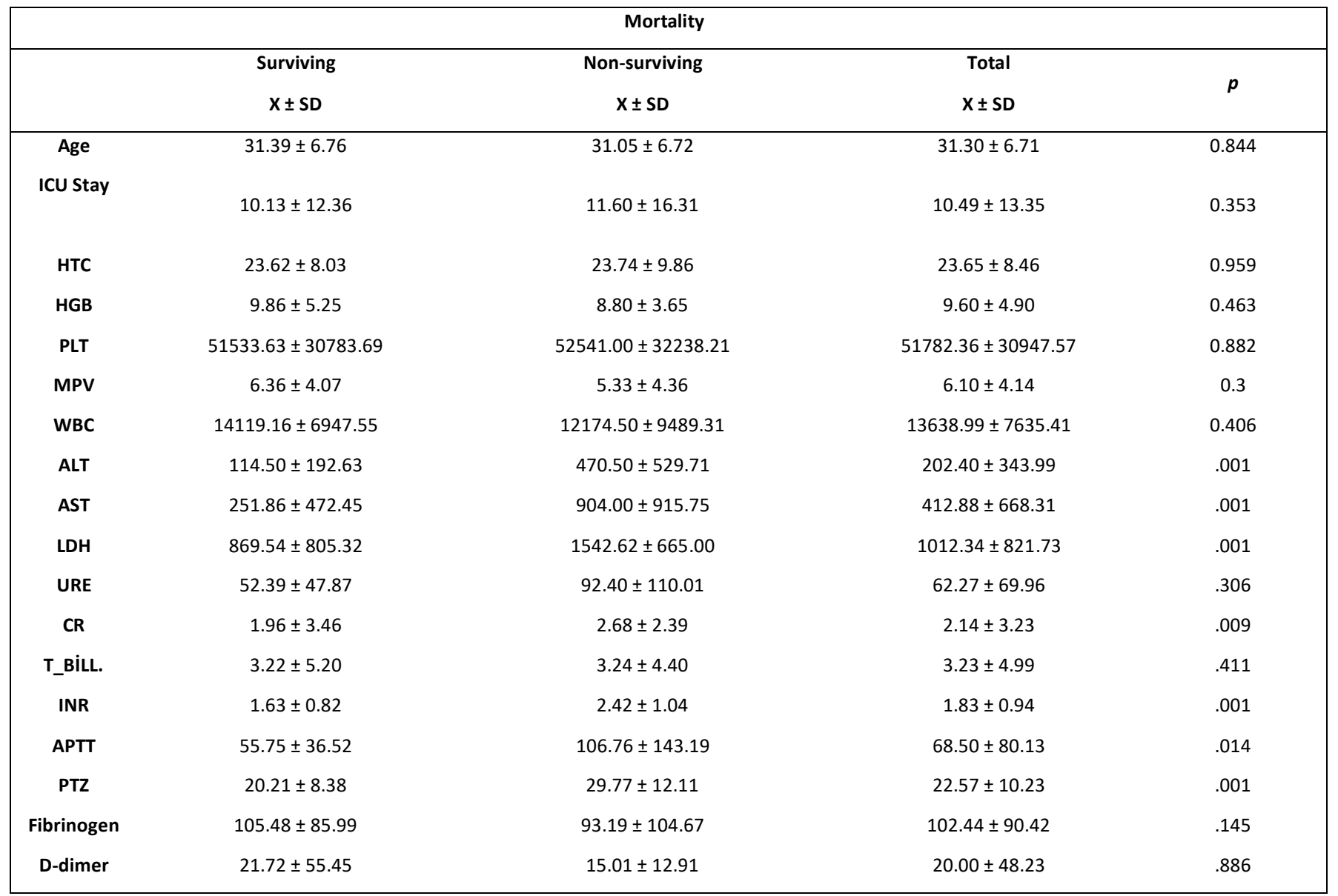

ICU: intensive care unit, ALT: alanine aminotransferase, AST: aspartate aminotransferase, LDH: lactate dehydrogenase, INR: international normalized ratio, aPTT: activated partial thromboplastin time, PTT: partial thromboplastin time $p<0.05$ statistically significant (in bold).

Table III: Mortality rates in the groups.

\begin{tabular}{|c|c|c|c|c|c|}
\hline & & \multicolumn{4}{|c|}{ Mortality Status } \\
\hline & & & Surviving & Non-surviving & \\
\hline \multirow{4}{*}{$\begin{array}{c}\text { DIC } \\
\text { GROUP }\end{array}$} & $H T$ & $\mathrm{n}(\%)$ & 15 (68.1\%) & $7(31.8 \%)$ & \multirow{4}{*}{0.153} \\
\hline & Hemorrhage & n (\%) & 32 (80\%) & $8(20 \%)$ & \\
\hline & $\begin{array}{c}\text { Ablatio } \\
\text { Placentae }\end{array}$ & n (\%) & 10 (90.9\%) & 1 (9.09\%) & \\
\hline & Others & $\mathrm{n}(\%)$ & 4 (50.0\%) & $4(50.0 \%)$ & \\
\hline
\end{tabular}

Overt DIC was diagnosed in patients with an ISTH score of $>5$. Table 4 presents the mortality rates with regards to the DIC scores. Table 5 presents multiple logistic regression analysis results based on the laboratory parameters. 
Table IV: Mortality rates based on the DIC scores.

\begin{tabular}{|clllll|}
\hline \multicolumn{5}{|c}{} & \multicolumn{4}{c|}{ DIC score } & $P$ \\
\hline \multirow{2}{*}{$\begin{array}{c}\text { Mortality } \\
\text { Status }\end{array}$} & Surviving & $\begin{array}{l}\text { Count } \\
(\%)\end{array}$ & $40(65.57 \%)$ & $21(34.43 \%)$ & \\
& $\begin{array}{l}\text { Non- } \\
\text { surviving }\end{array}$ & $\begin{array}{l}\text { Count } \\
(\%)\end{array}$ & $8(40.00 \%)$ & $12(60.00 \%)$ & 0.043 \\
\hline
\end{tabular}

Table V: Multiple logistic regression analysis results based on the laboratory parameters.

\begin{tabular}{|ccccc|}
\hline & & \multicolumn{3}{c|}{ Multivariate Logistic Regression } \\
\hline & $p$ & OR & \multicolumn{2}{c|}{ 95\% CI for OR } \\
& & & Lower & Upper \\
\hline ALT & 0.007 & 1.003 & 1.001 & 1.005 \\
INR & 0.040 & 1.803 & 1.027 & 3.167 \\
\hline
\end{tabular}

Of the 82 patients, 45 (54.87\%) did not undergo routine antenatal care, 14 (17.07\%) underwent regular antenatal care, and no information was available regarding the antenatal care in 23 $(28.04 \%)$ patients. Mortality occurred in 12 (26.6\%) of the patients who did not undergo routine antenatal care and in $3(21.42 \%)$ of the 14 patients who underwent regular antenatal care.

No complication occurred in the postpartum period in $22(26.82 \%)$ patients. Morbidity was detected in 40 patients, including respiratory failure (25\%), acute kidney failure (27\%), posterior reversible encephalopathy syndrome (PRES) (13.5\%), sepsis (10.8\%), and other

\section{DISCUSSION}

Disseminated intravascular coagulation (DIC) is characterized by the involvement of numerous etiological factors and is a confusing clinical condition that includes numerous variables and should be managed with a multidisciplinary approach. For these reasons, there is still no standard method for the treatment of DIC, and available treatment methods only target the underlying cause of DIC. Accordingly, treating the underlying condition and replacing the blood components and anticoagulants that are lost during this treatment are of vital importance? .

The reported incidence of DIC ranges between $0.03 \%$ and $0.35 \% \%^{8-9}$. Kor-anantakul et al ${ }^{10}$ reported the incidence of DIC as 1/1355 live births, whereas Rattray et al reported an incidence of 3/10 000 live births ${ }^{8}$. In our study, we found an incidence of 41/10 000 live births, which was higher than the rates previously reported. This finding could be attributed to the fact that our hospital is a tertiary referral hospital that serves a large population in the region and is equipped with advanced ICU facilities.

The literature shows that the rates of mortality resulting from DIC-induced acute kidney failure and cardiac arrest remain very high despite the ubiquity of surgical and medical treatment options that can remove the pathological process or eliminate the underlying cause of DIC . In our study, the mortality rate was $24 \%$ as opposed to the $60-80 \%$ reported in the literature ${ }^{11}$. This difference could be attributed to several causes, such as the availability of advanced medical and surgical techniques, easy access to blood components, and enhanced ICU facilities and capacity.

Patients with intrauterine fetal death caused by ablatio placentae have a poor prognosis, and the prognosis becomes even worse in the fetal deaths occurring after the 20th week of gestation. Such patients are requested to wait until the onset of spontaneous labor before the administration of prostaglandin analogs for labor induction. In most of these patients, labor often occurs within 3 weeks after the fetal death $^{12,13}$, but in $25 \%$ of the patients, labor may occur after 4 weeks. For these reasons, patients are monitored for spontaneous labor. However, within this period, the patients have an increased risk of coagulopathy and may develop chronic coagulopathy ${ }^{14,15}$. In our study, the most common cause of DIC was postpartum 
hemorrhage, followed by hypertensive pregnancies, ablatio placentae, and other conditions.

Thrombocytopenia is another key indicator of DIC which leads to longer ICU stay and is associated with poor prognosis ${ }^{16}$. However, in our study, various thrombocyte levels showed no significant difference in the mortality rate and the length of ICU stay.

Fibrinogen is an acute-phase reactant also used in the scoring of DCI. Wada et al reported that increased fibrinogen is associated with multiple organ failure and poor prognosis ${ }^{17}$. Similarly, we also found a significant difference between the surviving and non-surviving patients in terms of fibrinogen levels.

An analysis of the PTT and aPTT levels between the surviving and non-surviving patients revealed a significant correlation between increased PTT and aPTT levels and DIC-related mortality. In addition, the increase in other parameters, including ALT, AST, LDH, CR, INR, APTT, and PTZ, also established a significant correlation with DIC-related mortality. However, although urea was shown to be significantly correlated with DIC-related mortality in a previous study ${ }^{18}$, we found no such correlation, but in our study the multiple logistic regression analysis indicated that increased INR and ALT levels led to a significant increase in DIC-related mortality.

Recent reports indicate that DIC-related mortality has decreased within recent decades due to advances in the medical and surgical techniques and the growing number of healthcare centers that are capable of multidisciplinary approaches. In our study, there was no significant relationship between the underlying causes of DIC and mortality $(p=0.153)$. This finding suggests that the underlying cause of DIC has no effect on the risk of mortality caused by DIC.
Obstetrical DIC is commonly associated with postpartum hemorrhage. Therefore, transfusion of blood and blood products and replacement of the loss of oxygen and nutrients caused by shock and bleeding is of vital importance. In particular, prompt transfusion of erythrocyte suspension is essential. In cases of postpartum hemorrhage, rapid and aggressive transfusion often becomes a life-saving intervention. Following the erythrocyte suspension transfusion, a prompt evaluation of the blood levels and replacement of the missing blood components becomes mandatory. In our study, it was revealed that the surviving patients required more transfusion of blood products, except for random thrombocyte, compared to the non-surviving patients and these outcomes are presented in Figure 1.

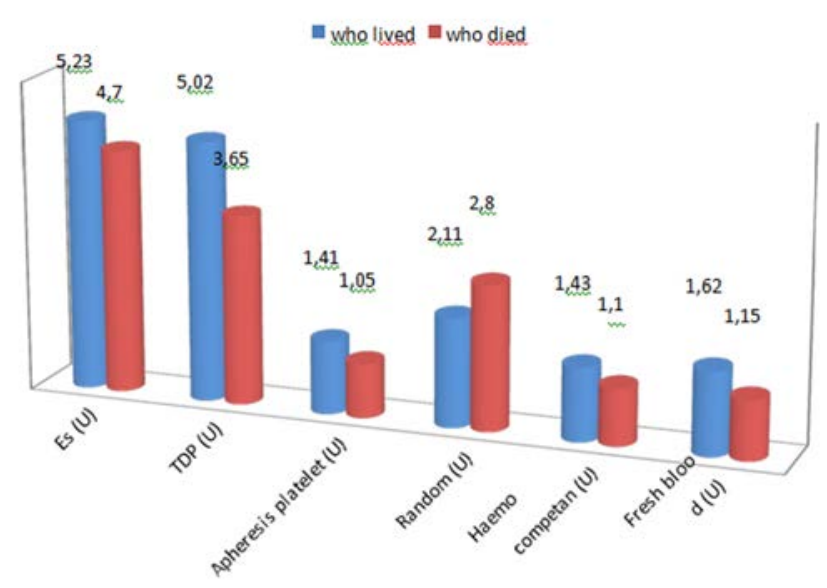

Figure 1. Transfusion of blood components with regards to mortality

In addition to blood transfusion, secondary surgery was also required in several patients, including dilation and curettage due to retained placenta $(n=1)$, total abdominal hysterectomy $(n=6)$, bilateral internal iliac artery ligation $(n=4)$, total abdominal hysterectomy with bilateral internal iliac artery ligation $(n=6), B-$ Lynch suture with bilateral internal iliac artery ligation $(n=5)$, subtotal hysterectomy $(n=1)$, and cervical laceration repair $(\mathrm{n}=1)$. 
An analysis on the relationship between the DIC scores and mortality indicated that the DIC score was $>5$ in $60.0 \%$ of the non-surviving patients and was $\leq 5$ in $65.57 \%$ of the surviving patients. It was also revealed that mortality occurred in $8 \%$ of the patients with a DIC score of $\leq 5$ and in $12 \%$ of the patients with a score of $>5$. Moreover, a significant correlation was found between the DIC scores and mortality $(p=0.043)$. These findings suggest that DIC scores can be used as a predictive marker for DIC-related mortality. However, no significant relationship was found between antenatal care and mortality $(p=0.896)$, and the multiple logistic regression analysis indicated that increased INR and ALT levels led to a significant increase in DIC-related mortality.

In conclusion, DIC can arise from obstetric conditions and results in high mortality and morbidity unless a rapid and aggressive intervention is performed. Moreover, laboratory workup and DIC scoring should be rapidly performed and the underlying cause of DIC should be promptly discovered. Since these procedures can only be performed via a multidisciplinary approach, the patient should be promptly transferred to the nearest tertiary referral hospital equipped with ICU facilities. An increase in laboratory parameters, particularly in ALT, AST, LDH, CR, INR, aPTT, and PTZ, can be predictive for multiple organ failure. INR and ALT are the most important laboratory parameters in DIC and also can affect mortality. In addition, DIC scoring can be a useful predictive marker for DIC-related mortality and thus can be useful in the diagnosis of DIC patients. Moreover, if DIC scoring can be specified in the future, it may lead to better classification of DIC patients based on their risk factors and thereby may facilitate the diagnosis of the underlying causes of DIC.

Ethics Committee Approval: The retrospective study included women with DIC who either had a delivery at Dicle University
Medical School Gynecology and Obstetrics Department or were referred to this department prior to delivery between May 2006 and May 2016. The study was approved by the local Ethics Committee (no:210).

Declaration of Conflicting Interests: The authors declare that they have no conflict of interest.

Financial Disclosure: No financial support was received.

\section{REFERENCES}

1. Papageorgiou C, Jourdi G, Adjambri E, et al. Disseminated Intravascular Coagulation: An Update on Pathogenesis, Diagnosis, and Therapeutic Strategies. 2018; 24: 8-28.

2. Gezer S. Dissemine intravasküler koagulasyonun tanı ve tedavisi. HematoLog. 2012; 2:2.

3. Rodger L. Syndromes of Disseminated Intravascular Coagulation in Obstetrics, Pregnancy and Gynecology: Objective Criteria for Diagnosis and Management. Hematology/Oncology Clinics of North America. 2000; 14: 999-1044.

4. Callaghan WM, Creanga AA, Kuklina EV. Severe maternal morbidity among delivery and postpartum hospitalizations in the United States. Obstet Gynecol. 2012; 120: 1029-36.

5. Levi M. Disseminated intravascular coagulation (DIC) in pregnancy and the peri-partum period. Thromb Res. 2009; 123: 63-4.

6. Peker N, Turan G, Aydın E, et al. Analysis of Patients Undergoing Peripartum Hysterectomy for Obstetric Causes According to Delivery Methods: 13Year Experience of a Tertiary Center. Dicle Med. Journal. 2020; 47: 122-9

7. Taylor FBJ, Toh $\mathrm{CH}$, Hoots WK, et al. Towards definition, clinical and laboratory criteria, and a scoring system for disseminated intravascular coagulation. Thromb Haemost. 2001; 86: 1327-30.

8. Rattray DD, 0'Colleen CM, Baskett TF. Acute disseminated intravascular coagulation in obstetrics: a tertiary centre population review (1980 to 2009). J Obstet Gynaecol Can. 2012; 34: 341-7. 
9. Erez O, Novack L, Beer-Weisel R, et al. DIC score in pregnant women - a population-based modification of the International Society on Thrombosis and Hemostasis score. PloS One. 2014; 9: 93240.

10. Kor-anantakul O, Lekhakula A. Overt disseminated intravascular coagulation in obstetric patients. J Med Assoc Thai. 2007; 90: 857-64.

11. Munoz MC, Montes R, Hermida J, et al. Effect of the administration of recombinant hirudin and/or tissue-plasminogen activator (t-PA) on endotoxininduced disseminated intravascular coagulation model in rabbits. Br J Haematol 1999; 105: 117-21.

12. Dippel AL. Bull. Johns Hopkins Hosp. 1934; 54: 24-34.

13. Tricomi V, Kohl SC. Fetal death in utero. Am J Obstet Gynecol 1957; 74: 1092-8.

14. Suresh I, Vijaykumar TR, Nandeesh HP. Predictors of Fetal and Maternal Outcome in the
Crucible of Hepatic Dysfunction During Pregnancy. Gastroenterology Res. 2017; 10: 21-7.

15. Brăila AD, Gluhovschi A, Neacşu A, et al. Placental abruption: etiopathogenic aspects, diagnostic and therapeutic implications. Rom J Morphol Embryol. 2018; 59: 187-95.

16. Vanderschueren S, De Weerdt A, Malbrain M, et al. Thrombocytopenia and prognosis in intensive care. Crit Care Med. 2000; 28: 1871-6.

17. Wada H, Mori Y, Okabayashi K, et al. High plasma fibrinogen level is associated with poor clinical outcome in DIC patients. Am J Hematol 2003; 72: 17.

18. Başaranoğlu S, Evsen MS, Ağaçayak E, et all. Evaluation of obstetrical patients with disseminated intravascular coagulopathy-tertiary center experience. J Matern Fetal Neonatal Med. 2016; 29 : 2929-33. 